\title{
Development of assisted road navigation by the drainage network
}

\author{
Talnan Jean Honoré Coulibaly ${ }^{1} \cdot$ Naga Coulibaly $^{1} \cdot$ Koffi Claude Alain Kouadio $^{1}$. \\ Jean Paul Deroin ${ }^{2} \cdot$ Mathurin Camara $^{1} \cdot$ Issiaka Savane $^{1}$
}

Received: 1 February 2016/Accepted: 4 February 2016/Published online: 27 February 2016

(C) Springer International Publishing Switzerland 2016

\begin{abstract}
The objective of the research is to analyze the relationship between drainage and assisted navigation on the road. More specifically, to show how the drainage contributes to assisted road navigation. First, we extract the drainage of SRTM picture. In a second step, we integrated drainage and roads in a geographic information system (GIS). Finally, we processed in GIS, drainage and road network in order to highlight the characteristics of risk areas, construction sites of bridges, dams and computer aided navigation. The study shows that the drainage network and the road network integrated into a GIS leads to the production of an application that allows users and road managers to learn about the state of the road and help decision. The resulting application is an effective information on the state of the tool to help drive on-road driving and road network management.
\end{abstract}

Keywords Drainage network $\cdot$ Road $\cdot$ Assisted navigation · GIS

\section{Introduction}

Used as early as the 1960s, the geographic information systems (GIS) are systems comprising multiple geographical databases, software management and access to information whose purpose is to centralize, organize, manage, and analyze the data and updating them. They are

Talnan Jean Honoré Coulibaly

ctalnan@yahoo.fr

1 Laboratoire Géosciences et Environnement, Université Nangui Abrogoua, 02 BP 801, Abidjan, Côte d'Ivoire

2 Université de Reims, Reims, France structured to be able to extract information or synthesis of useful information for decision-making (Denegre and Et Salge 1996).

GIS constitute an important contribution in environmental management policies. GIS have been the subject of much research, one of the outcomes was the establishment of powerful navigation systems useful to environmental management. These navigation systems have experienced and continue to know a great boom, especially with the advent of GPS (Global Positioning System).

They are also particularly powerful tools to locate continuously, plan trajectory (Elloumi et al. 2011), study and predict the risk of natural disasters (Wade et al. 2008), better to effectively manage the environment. They also allow to inform the user about the State of roads (areas prone or not, degraded or not...) and to guide its decisionmaking. For this, GIS are now needed as essential tools in the problem of sustainable development which aims to enable all human beings to satisfy its basic needs while preserving its environment.

It is in this context of sustainable development that fits the interests of the establishment of a system of assisted navigation taking into account environmental concerns. In this regard, we proposed to reflect on the relationship between the drainage network and assisted navigation. So far, no significant study on this subject was made.

In this perspective, is initiated a study whose theme is: "development of navigation on road by the drainage system".

The main objective of this work is to analyze the relationship between the drainage network and navigation on road. More specifically, to show how the drainage network helps navigation on road.

To do this, should gain a better understanding of the concepts of this theme. In hydrology, drainage basin or 
watershed is a geographical area bounded by the ridge line where the waters are organized into a drainage or drainage system. On this drained area, all the waters flowing to called the lowest point outfall, following the natural slope and join to form a river, a river, a lake or a slick underground (Goula 1993). The drainage or drainage network thus designates a set hierarchical and structured channels which provide drainage superficial, permanent or temporary, a given watershed. In other words, it is the watershed that supports the drainage network. The hierarchy of the network drainage is manifested by the increasing importance of its elements, since the original ramifications of upstream devoid of tributaries (so-called order in the Strahler classification, 1952), until the main drain. The numbers grow from 1 to 2, 3, 4, 5 order etc., depend of the size of the basin and the density of drainage (Savane 1997). The hydrographic network is even denser that the climate is more humid, the rains are more abundant, the highest slopes, rocks or permeable surfaces.

The navigation system is a driver assistance available for any moving object device. Thus, any navigation on road or track equipped with such a driving assistance device is said to be assisted (Auge 2006).

\section{Study area}

Our study site is the district of Abidjan located in the South of Côte d'Ivoire can also be seen in Fig. 1. Its coordinates in the UTM vary from 374,000 to $394,000 \mathrm{~m}$ in Longitude and from 588,000 to $605,000 \mathrm{~m}$ in Latitude.

The climate of the study area is an equatorial climate of transition. This climate has four seasons in the cycle annual (Tapsoba 1990; Kouame 2007; Allé 2013):

- a long dry season from December to April;

- a great from May to July rainy season;

- a small dry season from July to September;

- a short season of rains from October to November.

The main rainy season is centered on June while the short season is located in October (Kouame 2007; Allé 2013). For dry seasons, the large and the small are centered respectively in January and August.

Annual rainfall ranges from 1500 to over $2500 \mathrm{~mm}$ per year, divided between 90 to 180 days of precipitation (Combres and Et Eldin 1971). The average of rainfall between the periods from 2000 to 2009 showed a minimum of $18 \mathrm{~mm}$ in the month of August, and a maximum of $434 \mathrm{~mm}$ in June.

Average annual temperature recorded over the period from 1990 to 2003 in Abidjan have shown that the months of February, March and April are the hottest with temperatures above $28{ }^{\circ} \mathrm{C}$ while the less hot months are July,
August and September with a temperature below $25{ }^{\circ} \mathrm{C}$ (Kouame, 2007; Allé 2013). Annual variation in temperature is low $\left(+4{ }^{\circ} \mathrm{C}\right)$ due to the influence of the ocean. It is the same for monthly temperature range which is $7{ }^{\circ} \mathrm{C}$ in dry season and $5^{\circ} \mathrm{C}$ in season rainy (Tapsoba 1990; Kouame 2007).

\section{The materiel}

- 1 digital camera for images;

- 1 GPS;

- SRTM images of the study area, N05W004 and N05W005 with $90 \mathrm{~m}$ of resolution provided by the United States Geological Survey (USGS) (2004).

- Quantum GIS (QGIS) with GRASS GIS for the management of data, analysis, image processing, the production of maps, spatial modeling, and visualization. The choice of these free software is justified by the fact that unlike proprietary software, they are provided with source code. What gives us the opportunity to improve, to adapt, to see and understand numerical and statistical methods applied by the software to our data.

\section{The methodology}

Acquisition and collection of images of the study area The images were taken from a digital camera, taking into account the natural drainage of surface water. Points taken, marked in UTM (Universal Transverse Mercator) by GPS coordinates, have been selected on our study site to obtain the representative images of areas at risk of flooding, construction of bridges, nozzles and deterioration of the road network. These resulting images are collected and integrated into a GIS through their UTM coordinates. The methodology used here is therefore based on the choice of images that meet the best objective research and their integration in a GIS to bring out the characteristic zones of our study.

Acquisition of administrative, boundaries SRTM slabs and road network The administrative boundaries as well as the road network of the city of Abidjan used for this study was provided by the CNTIG (National Committee of remote sensing and geographical information). As for the SRTM images: N05W005 and N05W004 of $90 \mathrm{~m}$ resolution, they have to source the United States Geological Survey (USGS, 2004). All this data are loaded in QGIS.

Analysis of watersheds This step allowed us to first extract the study area, then the accumulation card basin and finally the hydrographic network. To do this, it is important 


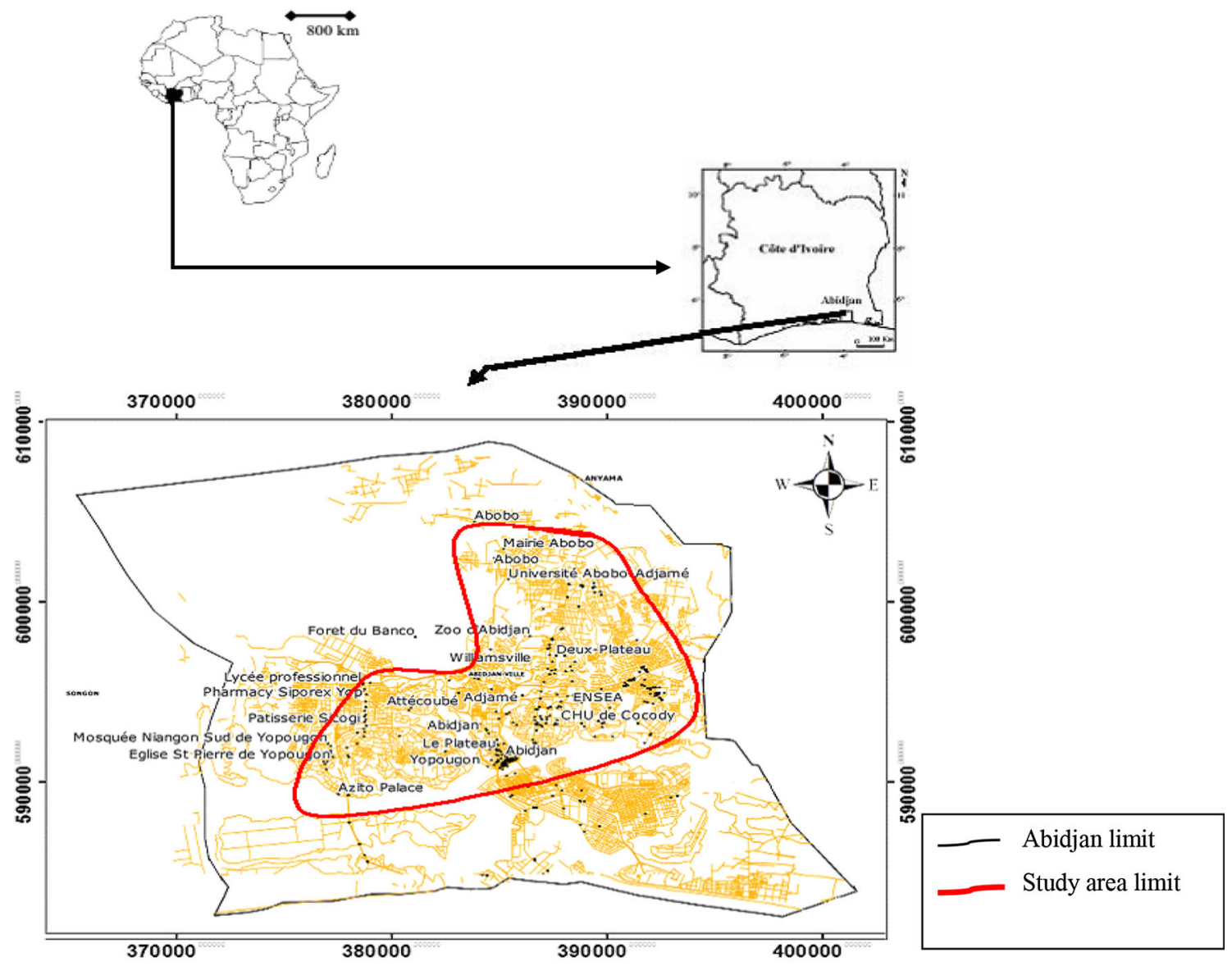

Fig. 1 Map of the study area

to present initially in a succinct manner the method we used, before proceeding to the extraction step.

\section{Description of the approach used}

The approach used in this study is the algorithm of connectedness eight (D8) which considers eight directions (Fig. 2).

Interest in this approach is the timeliness getting of information and its systematization allows to have relevant information on an entire region (Puech 1997 cited by

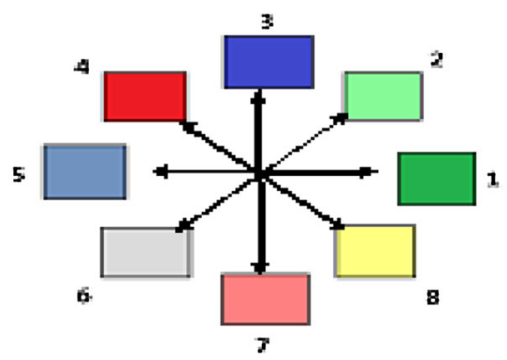

Fig. 2 Calculation of the connection algorithm Directions eight (D8) (anonymous source)
Coulibaly 2009). It appears all the more interesting that it can be applied to large surfaces without constraint legal or border. With this algorithm, the main difficulty in the typological approach - which is taking account of the links existing between these different sets (links which regulate the hydrological functioning) - is bypassed. These sets may occur either in the form of a hydrosequence continues with an upstream-downstream ordering (slope, glacis, Valley), or in the form of a discontinuous set whose elements work separately because of the presence of several reliefs. The presented method is efficient to find and retrieve the settings of a watershed from images SRTM. The algorithm is to move into the cloud of points of a grid (the file format used by the D8 algorithm) file by following precise rules of propagation, and then to measure the value of each cell of the matrix to finally assign item to a given class (slope, line of Ridge, line thalweg) (Coulibaly 2009). It appears that images SRTM are previously treated before any extraction of watershed and drainage system subsequently. This treatment is carried out as follows:

- Step 1 Mosaic and formatting of the base image from image processing software. 
The study area is covered by several SRTM tiles. With an image processing software we initially made a mosaic with different tiles which led to form a single image of our study area. In a second step we converted the mosaic file extension.hgt to grid format. Finally we integrated the grid file in the processing environment. The grid file is coded in 32 bits, which allows for more than 4 billion worth of possibilities for each cell.

- Step 2 Pretreatment of the file grid by deletion of the imperfections of the file. This step is to clear the sink effect due to imperfections in the grid file. Indeed, locally, on the gate of the low points file (the point of the altitude value is lower than all its neighbors) can prevent the flow of water and distort the river system. The model makes the location of cells with a lower value than all their neighbors and the minimum value applied neighbors (Payraudeau 2002).

- Step 3 Determination of directions of flow calculation of slopes. Calculation of slope to calculate the direction of flow in the direction of the highest slope determined. "The algorithm considers D8 flow directions along a unidirectional flow in eight connectivities, taking into account the eight neighboring cells of the considered point" (Charleux-Demargne 2001). It assigns a code depending on the relative position of the cell with the lowest elevation. A flow direction matrix is thus obtained (Fig. 3).

- Step 4 Extraction of drainage network. To determine the water system, the connectivity algorithm uses a threshold of appearance of the water, or critical drained surface. A pixel DTM is considered river if it exceeds a certain threshold set by the user. The extraction of river network is preceded by calculating the drained areas (Fig. 3). Each pixel of the DTM is assigned the number of pixels situated upstream according to the flow directions. Thus, for a given pixel value of the pixels situated upstream will determine the extent of the drainage area (Renaud 2006). However, obtaining the most relevant cards requires intermediate calculations (Fig. 3).

ETAPE I

\begin{tabular}{|l|l|l|l|}
\hline 33 & 38 & 42 & 43 \\
\hline 35 & 30 & 28 & 25 \\
\hline 40 & 37 & 34 & 21 \\
\hline 43 & 39 & 41 & 17 \\
\hline \multicolumn{4}{|c|}{$\begin{array}{c}\text { Modèle de } \\
\text { terrain }\end{array}$}
\end{tabular}

ETAPE II

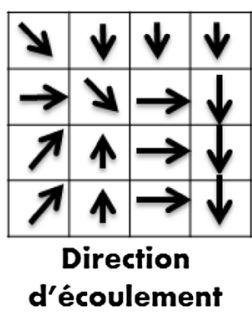

Schematic interpretation of a file from the eight connectivity algorithm

\section{Watersheds and the accumulation card extraction}

This can be done automatically using the $r$.watershed of the GRASS GIS software module (Raster $>$ hydrological modelling > analysis of watershed) to identify all basins with a minimum area of $1 \mathrm{~km}$ square.

The following parameters must be provided:

Name of MNT [input: elevation upon which the whole analysis is based: our raster named ABIDJAN. ]

Minimum of a basin area [Input value: minimum size of watershed outside]: Let's enter 1000

Name of the layer of accumulation (output channel: number of cells flowing in other cells) : Let's enter: accumulation

Name of the layer containing the basins (output channel: unique label for each watershed): Let's enter: basins

$r$.watershed gives the map a color "random' table. Using the r.colors module (Raster- > manage color > color Tables), it is possible to change the color table, for example by using the "Rainbow"' table.

\section{Extraction of the hydrographic network}

It is from the map of accumulation obtained we will extract the hydrographic network. For this operation, it uses the GRASS GIS Calculator Raster (Raster->map calculator), i.e. the

ETAPE III

\begin{tabular}{|l|l|l|l|}
\hline 1 & 1 & 1 & 1 \\
\hline 1 & 6 & 3 & 3 \\
\hline 1 & 2 & 1 & 3 \\
\hline 1 & 1 & 1 & 3 \\
\hline \multicolumn{4}{|c|}{ Réseau de } \\
drainage
\end{tabular}

ETAPE IV

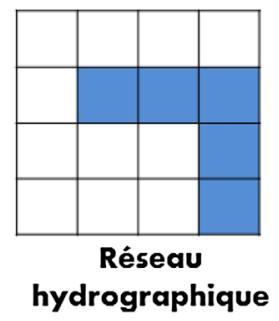


module r.mapcalc. We begin by calculating the logarithm of the absolute value of the accumulation named (Iog_accumulation), a useful parameter for hydrological calculations, the formula used is:

log_accumulation $=$ log (abs (accumula tion) +1$)$.

The GRASS command is:

\section{$r$ mapcalclog_accumulation $=\log \quad(a b s$ (accumulation) +1 ). \\ It again uses $r$.mapcalc to retrieve this layer drainage with a threshold of 6 . The \\ 1 is set to cells which the logarithm is greater than 6 and 0 for others, in order to get the raster layer with the hydro- graphic network and named network. \\ NETWORK = if}

( log_accumulationeraster $>6$ )

The GRASS command is:

$r . m a p c a l c$ network = if (log_accumulationaraster $>6$ ) .

Can replace the value of 6 by larger values if a network with less of tributaries.

Finally, to create a vector layer of the hydrographic network, r.thin (Raster> transform objects) will first be used to refine cells with linear entities in our raster (network), and then using the module $\boldsymbol{r}$.to.vect (file-> map-> Raster to vector type conversions), it is possible to create a new linear vector layer.

\section{Crossing of the road network and drainage network}

The GRASS GIS software allowed us to extract the hydrographic network of the study area. From software QGIS, we crossed the vector layers the hydrographic network and the road network (option "nouvelle vector layer

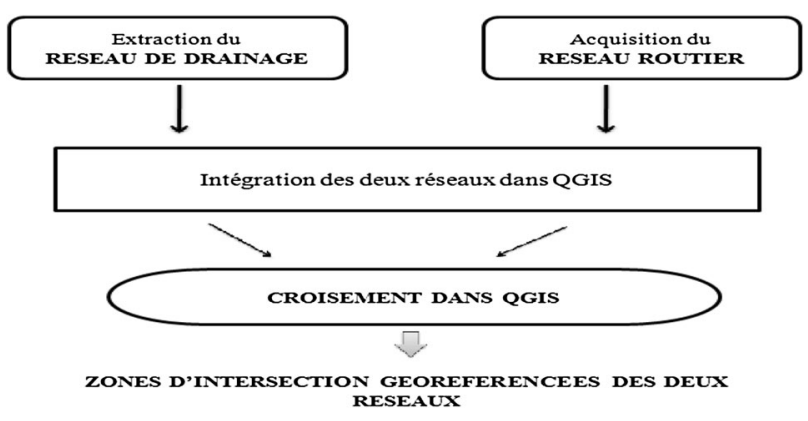

Fig. 3 Crossing of the drainage and the road network in a GIS network
1") that we have loaded. Coordinates in UTM images of land, previously organized in a spreadsheet (Excel) to CSV format, were also loaded into QGIS ("option "ajouter a layer of text delimited"). So, we got a map highlighting areas of intersection of the two networks (Fig. 3).

\section{Results}

The extraction steps have allowed us to obtain, from images processed, SRTM map of watersheds and map of accumulation of the waters of the study area. From the map of accumulation, we also extracted the hydrographic network file raster and vector file map. It is this layer vector of the hydrographic network which has been loaded into QGIS and with the road network.

The intersection of the drainage network and road network of the study area in QGIS software has enabled us to map areas under the stress of flows and on susceptible areas to be feature of civil engineering (bridges, embankments...). These areas are represented by red dots on the map below (Fig. 4):

The intersection of the drainage system and the road network system, highlights on digital map are in fact risks area. At these places, we used to have floods, sites for the construction of special civil engineering structures (bridges...) and areas of deterioration of the road network by the natural drainage of rain water.

From these results, the intersection zones are areas which must have a particular attention in the management of all kind of civil engineering or of environment project.

The hierarchy of the network drainage shows the proximity from the main branch of river to other river branches.

The number order of it grows (order 2 orders 3, 4, 5, etc.) with the size of the basin, the number of river branches and drainage density.

This hierarchy plays a key role in the type of civil engineering structures to build. More the civil engineering structures to build is near the main branches; more the work will be big and important.

All such information collected with GIS software, once integrated into a GPS constitute a powerful tool for navigation on road and a powerful tool to manage civil engineering projects.

This tool is very effective to locate areas at risk, the areas of depressions, the high points and the low points of a route. It also allows to assess the dimensions and the degree of the slopes (high, low or zero) and anticipate routes and suitable sites for construction. It is an effective tool of navigation, assistance for the maintenance and monitoring of roads; beyond an efficient helper application to road safety. Thus, this tool is an intelligent system that allows not only to warn the user, to provide reliable and useful in 
Fig. 4 Map for representative of a few crossing points of the network of drainage and road network in QGIS

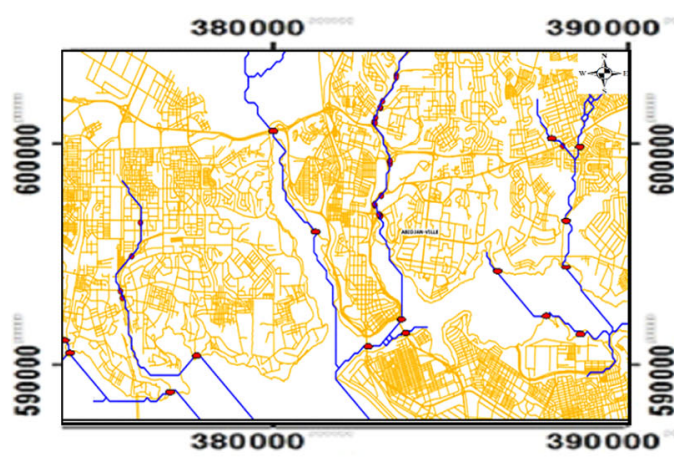

$\checkmark$ Points d'intersection géoréférencés:

- zones de construction des ouvrages de génie civil (ponts, buses,...) -zones à risques d'inondation

- zones de dégradation du réseau routier par le réseau de drainage

$\checkmark$ L'intelligence de notre système est basée sur cette carte

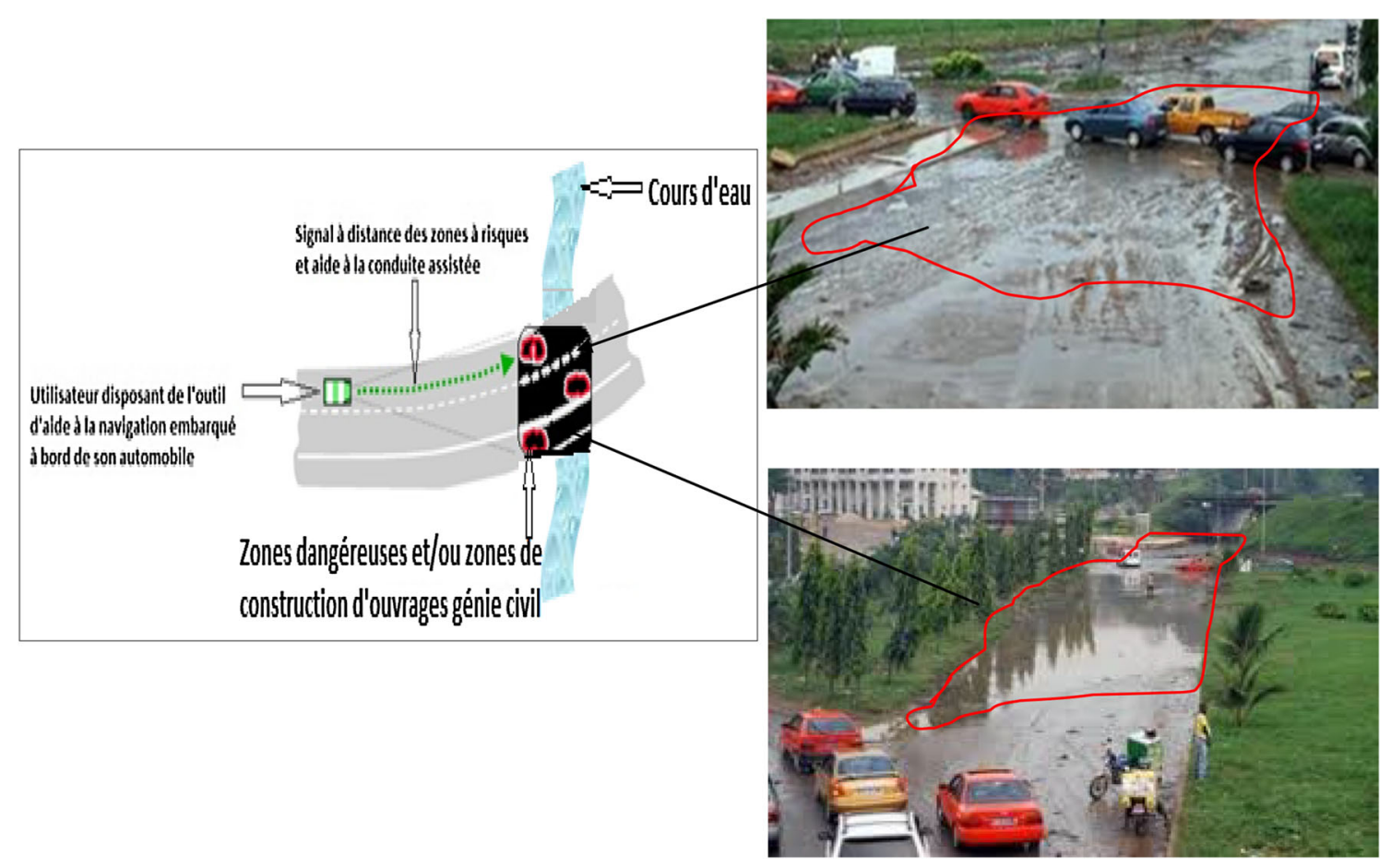

Fig. 5 Overview of the application support to assisted navigation tool

its decision-making information but also to assist in the management and forecasting roads. It appears as:

- The application is a tool of assisted navigation aid

The obtained previous map shows points of intersection (in red) which are the joint areas of the hydrographic network (in blue) and the road network (in orange). Wherever the crosses are materialized by the points in red, we encounter works of civil engineering such as bridges, nozzles, and flood risk areas. So, once integrated into a GPS embedded aboard an automobile or installed on a motorcycle or a bicycle to signal to the user, the approach to flood risk areas, areas of construction of bridges, nozzles, and therefore learn about the road to guide and assist in the conduct. The application is so to speak a driving assistance device displayed on screen better vehicles it is an intelligent navigation system on road.

The following field photographs have areas at risk, needing attention. These areas that can be reported a user with the application of assisted driving assistance remotely. This concept is clearly illustrated by the following schematic representation (Fig. 5).

- The application is a tool for management and maintenance of roads 


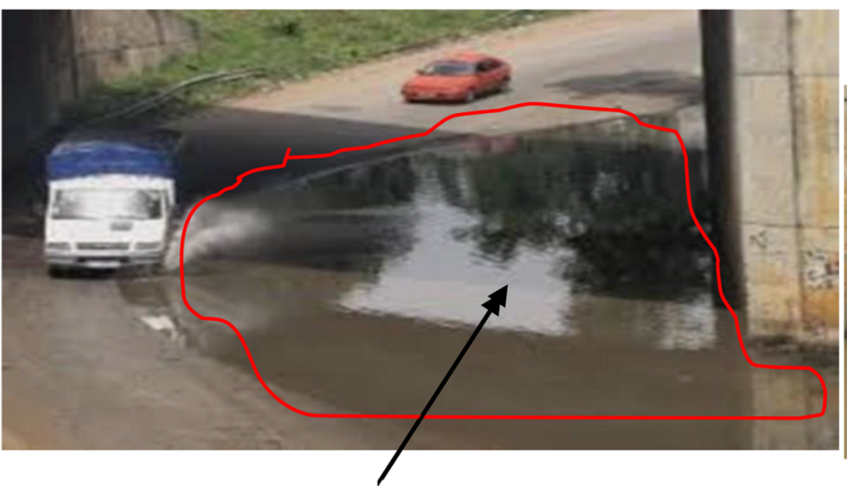

(a)

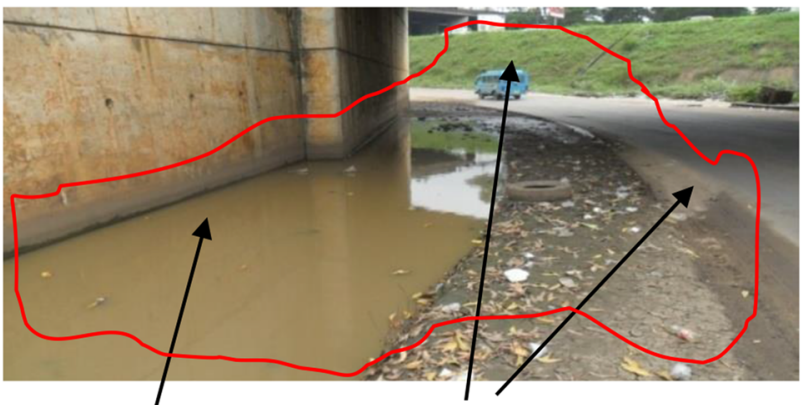

(b) (c)

Zones d'inondation et de dégradation de la route par le drainage des eaux

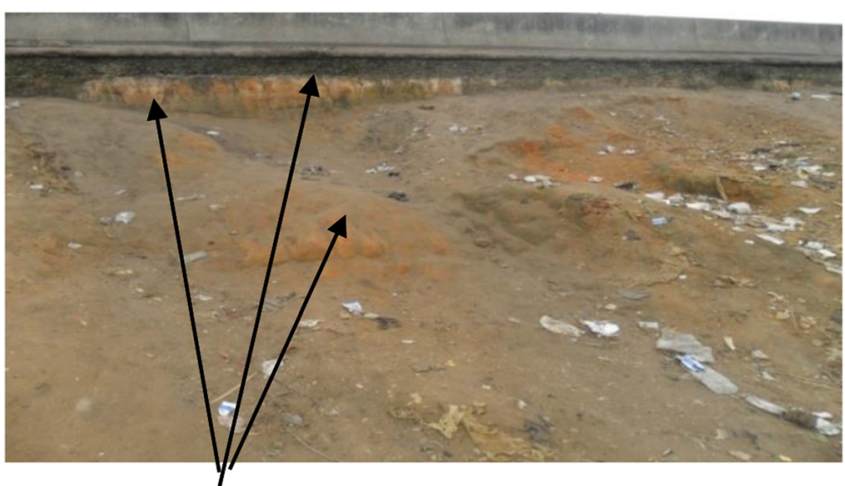

(d)

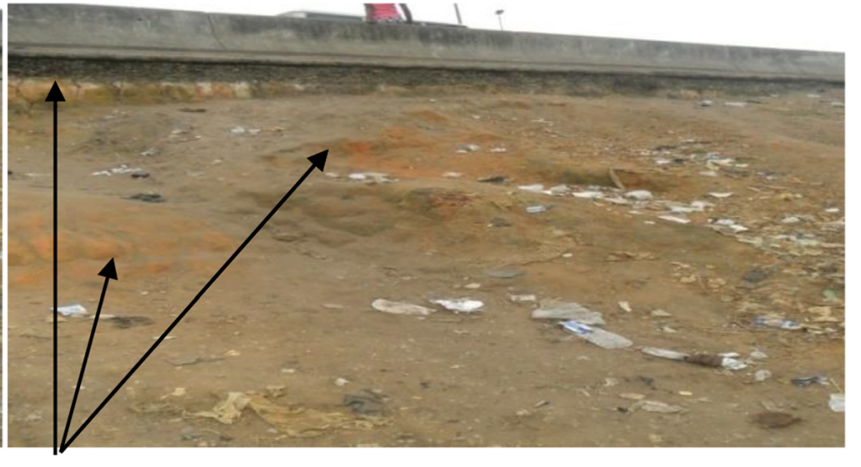

(e)

Route mise en péril par l'érosion due au drainage naturel des eaux

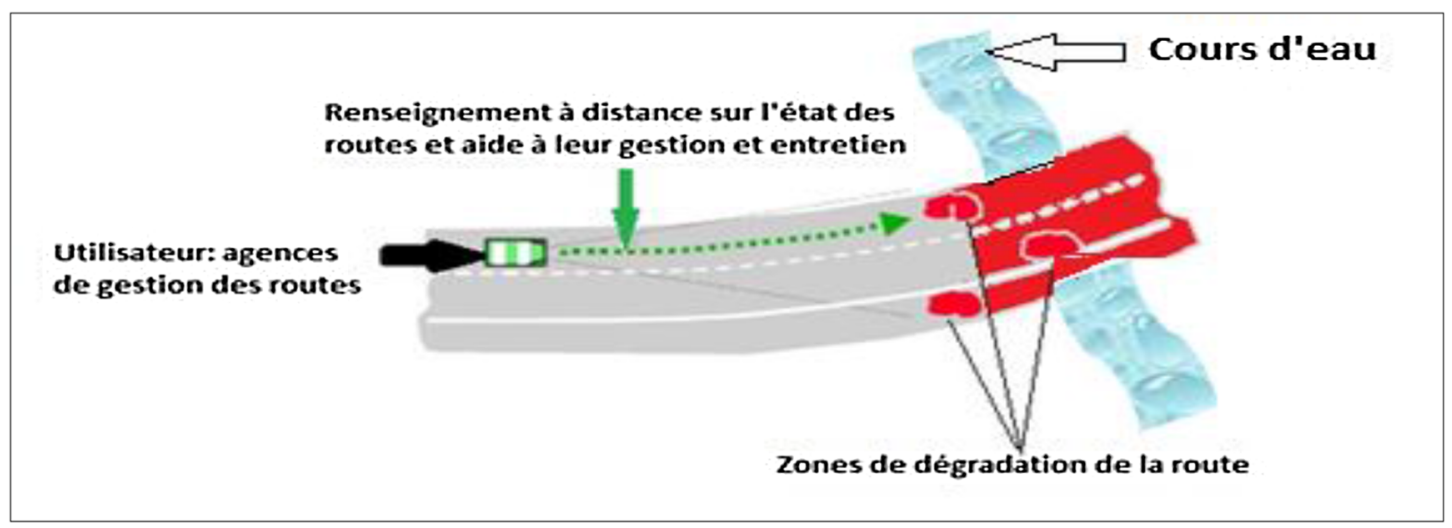

Fig. 6 Overview of the application management and maintenance tool. a-c Zones d'inondation et de dégradation de la route par le drainage des eaux. d, e Route mise en péril par l'érosion due au drainage naturel des eaux

The main cause of degradation at the intersection of roads of the road network and the drainage system, it is due to the effect of water. The tool allows to inform the user of the road to the probable presence of a degrading or dangerous area each time that it will be close to a major intersection area. We recall that the risk areas are mapped in GIS and are transferred to the GPS navigation.
This tools allows monitoring and maintenance of the road network. The following pictures have areas of flooding and damage to the road drainage water [(a), (b), (c), (d) and (e)]. The application can also present as a management tool and maintenance of the road network for road management agencies. It is an information system of the road network (Fig. 6). 


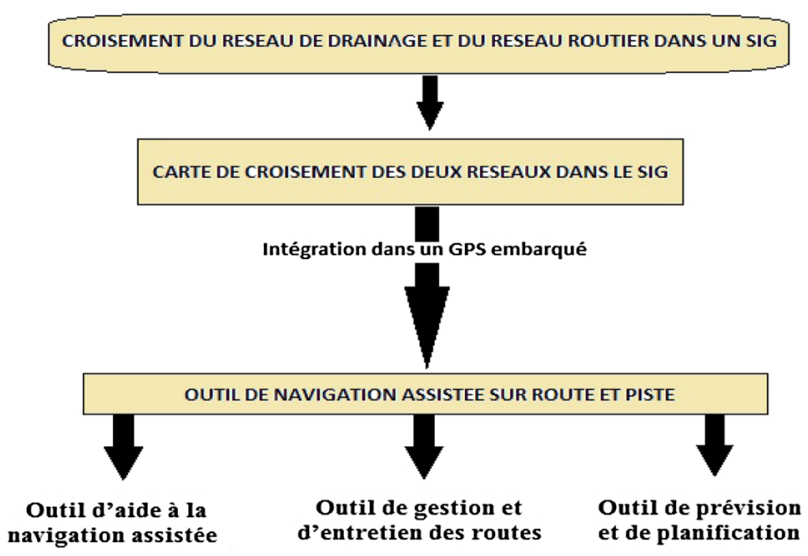

Fig. 7 Summary of results

- The application is a tool for forecasting and planning

The application presents itself also as a tool for forecasting and planning. It finds its usefulness in nonurbanized areas where it allows for the construction of new highways and other civil engineering works. It allows to predict their length, their cost, their implementation, etc. In addition, it enables to plan routes and suitable sites for the construction of civil engineering works (Figs. 4, 7).

\section{Discussion}

The objective of our work is to show how the drainage network helps navigation on road. To achieve this, we have crossed into a geographic information system (GIS), the drainage network of the study area to the road network of the same area. We were able to show that the resulting application is not only a tool to aid to navigation assisted on road, but also a tool of management, maintenance and forecasting of road networks.

Analysis of the drainage network, allowed us to highlight his significant contribution in the navigation on the roads. Through the application of aid to navigation, the geolocation of areas at risk is necessary for their best taken into account in the management of the environment. This is why our study is for us a particular interest.

Beyond the approach on GIS, developed in this work, we also opens a broader view on the concept of assisted navigation. Gillieron and Et Chazal (2010) many applications also use the GPS: it is by examples of the management of fleets of vehicles, especially in localization by satellites, collision avoidance, of information about routes and guidance during the journey, the trail location, etc.

A study conducted by (Wade et al. 2008) also presents the use of remote sensing and GIS in the management of natural disasters. The study has shown that remote sensing and GIS are powerful tools that apply perfectly to the management and forecasting of floods, water erosion and the gullies. By the crossing, in a GIS, images collected, you arrive to highlight information on areas of flood risk, magnitude and extent. The GIS layers include also the maps of occupation and land use, maps of urbanized areas and flooded areas, the digital field, hydrological, socioeconomic data, models etc. (Wade 2008). On the other hand, we have areas that are affected during every crisis, and therefore those who are most vulnerable (Dey et al. 2006).

Thus, the study that we conducted approximates both Gillieron and Et Chazal (2010) and Wade et al. (2008). Because these two studies have led to the establishment of a tool: a GIS to provide useful information to assist in an alert and quick decision making. And this for the efficient management of the environment, in the context of sustainable development.

\section{Conclusion}

The objective set for this study was to analyze the relationship between the drainage network and navigation on road. More specifically, to show how the drainage network helps navigation on road.

To achieve this goal, we loaded and crossed in a GIS software free QGIS, the drainage network and the road network of the study area. The crossing card obtained allowed us to highlight the areas of intersection of the two networks. These areas are sites that are characteristic of construction of civil engineering structures (bridges, culverts...), flood-prone areas and areas of deterioration of the road network by the natural drainage of water.

By the crossing of these two networks in GIS, we have achieved thus obtaining a card, once integrated into a GPS embedded in a vehicle, presents itself as a true tool of assisted navigation aid, which allows to orient the user and assist in decision making. It helps in addition to monitoring, maintenance, prediction and the effective management of the roads.

Our study shows that the use of the Information System geographic (GIS) allowed us to highlight the drainage system and to analyze its contribution in assisted road navigation. Beyond that, the GIS are necessary as an efficient environmental management tool.

\section{References}

Allé CS, Ulrich Y, Afouda AA, Agbossou KE, Guibert H (2013) Am J Sci Res 94:55-68. http://www.americanjournalofscientificre search.com

Auge C (2006) Le Petit Larousse illustré. Hachette, Paris 
Combres JC, Et Eldin M (1971) Eléments généraux du climat. In: Atlas Côte d'Ivoire. Ministère du plan/ORSTOM/Institut de Géographie Tropicale, Abidjan, 2 pl. texte, 1 pl. carte

Coulibaly TJH (2009) Répartition spatiale, Gestion et Exploitation des eaux souterraines: Cas du département de Katiola, région des savanes de Côte d'Ivoire. Thèse Université d'Abobo-Adjamé, version 1 du 7 Nov. 2011, p 135

Charleux-Demargne J (2001) Qualité des Modèles Numériques de Terrain pour l'hydrologie. Application à la caractérisation des crues des bassins versants. Thèse de Sciences de l'Information, Géographique, Université de Marne la Vallée, France

Denegre J, Et Salge F (1996) Les Systèmes d'Information Géographique. Collection: Que sais-je? Ed Presses Universitaires de France, No 3122, p 128

Dey et al (2006) Three-dimensional geologic mapping of groundwater resources in Kane County, Illinois. In: Russell HAJ, Berg RC, Thorleifson LH (eds) Three-dimensional geological mapping for groundwater applications: Workshop extended abstracts. Geological Survey of Canada, Ottawa, p 109

Elloumi W, Leconge R, Royer E, Et Treuillet S (2011) Localisation pédestre: Synthèse bibliographique et illustration d'une approche par vision monoculaire embarquée

Gillieron P-Y, Et Chazal V (2010) Perspectives et applications des méthodes de navigation pour la télématique des transports routiers et pour le système d'information de la route

Goula BTA (1993) Modélisation hydrologique de bassins versants équipés d'ouvrages hydrauliques en zone soudano-sahélienne: Application au Massili (Burkina Faso). Thèse de doctorat, Ecole Nationale Supérieure des Mines de Paris

Kouame KI (2007) Pollution physico-chimique des eaux dans la zone de la décharge d'Akouédo et analyse du risque de contamination de la nappe d'Abidjan par un modèle de simulation des écoulements et du transport des polluants. Thèse unique. Université Abobo-Adjamé, pp 8-40

Payraudeau S (2002) Modélisation distribuée des flux d'azote sur des petits bassins versants méditerranéens. Doctorat Sciences de l'Eau, UMR Structures et Systèmes Spatiaux Cemagref, Engref de Montpellier, ENGREF, p 436

Puech C (1997) Remote sensing and water resources; Proceedings of the international workshop Series title: Water reports 1997. W7320/B, 1st edn. Food and Agriculture Organization of the United Nations, Rome

Renaud J (2006) Université St Etienne France, Mise en place du modèle agroenvironnemental SWAT sur le bassin versant du Mercube (Haute-Savoie): Vers une modélisation des transferts de phosphore, p 75

Savane I (1997) Contribution à l'étude géologique et hydrogéologique des aquifères discontinus du socle cristallin d'Odienné (NordOuest de la Côte d'Ivoire). Apport de la télédétection et d'un système d'information hydrogéologique à référence spatiale. Thèse d'Etat Univ. Cocody, partie1, pp 38-40

Tapsoba SA (1990) Etude géologique et hydrogéologique du bassin sédimentaire de la Côte d'Ivoire: Recharge et qualité des eaux dans l'aquifère côtier (Région de Jacqueville). DEA, Université Cheick Anta Diop-Dakar, p 69

Wade S, Rudant JP, Ba K, Et Ndoye B (2008) Télédétection et gestion des catastrophes naturelles: Applications à l'étude des inondations urbaines de Saint Louis et du ravinement lié à l'érosion hydrique à Nioro-du-Rip (Sénégal). Revue Télédétection, 2008, vol. 8, no 3, pp 203-210 